\title{
Sphingosylphosphorylcholine Antagonizes Proton-Sensing Ovarian Cancer G-Protein-Coupled Receptor 1 (OGR1)-Mediated Inositol Phosphate Production and cAMP Accumulation
}

\author{
Chihiro Mogi ${ }^{1}$, Hideaki Tomura ${ }^{1}$, Masayuki Tobo ${ }^{1}$, Ju-Qiang Wang ${ }^{1}$, Alatangaole Damirin ${ }^{1}$, Junko Kon ${ }^{1}$, \\ Mayumi Komachi ${ }^{1}$, Kinji Hashimoto ${ }^{2}$, Koichi Sato ${ }^{1}$, and Fumikazu Okajima ${ }^{1, *}$ \\ ${ }^{1}$ Laboratory of Signal Transduction, Institute for Molecular and Cellular Regulation, Gunma University, \\ Maebashi 371-8512, Japan \\ ${ }^{2}$ Nutrition Research Institute, Otsuka Pharmaceutical Factory, Inc., Muya-cho, Naruto, Tokushima 772-8601, Japan
}

Received July 4, 2005; Accepted August 8, 2005

\begin{abstract}
Ovarian cancer G-protein-coupled receptor 1 (OGR1), previously proposed as a receptor for sphingosylphosphorylcholine (SPC), has recently been identified as a proton-sensing or extracellular $\mathrm{pH}$-responsive G-protein-coupled receptor stimulating inositol phosphate production, reflecting the activation of phospholipase $\mathrm{C}$. In the present study, we found that acidic $\mathrm{pH}$ stimulated cAMP accumulation, reflecting the activation of adenylyl cyclase, in addition to inositol phosphate production in OGR1-expressing cells. The cAMP response was hardly affected by the inhibition of phospholipase $\mathrm{C}$. SPC inhibited the acidification-induced actions in a pH-dependent manner, while no OGR1-dependent agonistic action of SPC was observed. Thus, the dose-response curves of the proton-induced actions were shifted to the right in the presence of SPC regardless of stereoisoform. The antagonistic property was also observed for psychosine and glucosylsphingosine. In conclusion, OGR1 stimulation may lead to the activation of adenylyl cyclase in addition to phospholipase $\mathrm{C}$ in response to extracellular acidification but not to SPC. However, SPC and related lysolipids antagonize the proton-induced and OGR1-mediated actions.
\end{abstract}

Keywords: ovarian cancer G-protein-coupled receptor 1 (OGR1), sphingosylphosphorylcholine, psychosine, G-protein-coupled receptor, proton-sensing

\section{Introduction}

Ovarian cancer G-protein-coupled receptor 1 (OGR1) was initially identified as a receptor for sphingosylphosphorylcholine (SPC) to induce $\mathrm{Ca}^{2+}$ mobilization, stimulate extracellular signal-regulated kinase (ERK), and inhibit proliferation (1). A recent study, however, has shown that OGR1 stimulates inositol phosphate production and the subsequent $\mathrm{Ca}^{2+}$ mobilization in response to neutral-to-acidic extracellular $\mathrm{pH}(2)$. Thus, either SPC or proton seems to stimulate the phospholipase $\mathrm{C} / \mathrm{Ca}^{2+}$ system. Furthermore, GPR4, G2A, and $\mathrm{T}$ cell death-associated gene 8 (TDAG8), which are closely related G-protein-coupled receptors (GPCRs) to OGR1 and have been reported to be receptors for

*Corresponding author. FAX: +81-27-220-8895

E-mail: fokajima@showa.gunma-u.ac.jp lysolipids, such as SPC $(3,4)$, lysophosphatidylcholine (LPC) $(3,4)$, and psychosine (5), have also been shown to stimulate a variety of intracellular signaling pathways, including $\mathrm{G}_{\mathrm{s}}$ /adenylyl cyclase/cAMP, $\mathrm{G}_{\mathrm{q}}$ /phospholipase $\mathrm{C} / \mathrm{Ca}^{2+}$, and $\mathrm{G}_{13} / \mathrm{Rho}$, in response to the extracellular acidification (2, 6-9). Thus, OGR1, GPR4, G2A, and TDAG8 seem to form a unique family of GPCRs that not only recognize lipid mediators but also sense extracellular protons.

We have recently shown that psychosine, a proposed lipid ligand for TDAG8 (5), behaves as an antagonist rather than agonist against proton-induced adenylyl cyclase activation (7). Furthermore, lysophosphatidylcholine (LPC), a postulated ligand for G2A, has also been shown to antagonize the proton-induced G2Amediated actions (6). These observations prompted us to examine the relationship between two proposed ligands, that is, proton and SPC, on OGR1. Our results suggest 
that SPC, in a stereoisoform-independent manner, antagonizes the proton-induced actions mediated by OGR1. During the characterization of OGR1 signalings, we also found that acidification induced cAMP accumulation independently of the inositol phosphate production in OGR1-expressing cells.

\section{Materials and Methods}

\section{Materials}

Psychosine (galactosylsphingosine), glucosylsphingosine, D-erythro-sphingosine, and prostaglandin $\mathrm{E}_{2}$ $\left(\mathrm{PGE}_{2}\right)$ were purchased from Sigma-Aldrich (St. Louis, MO, USA); L- $\alpha$-lysophosphatidylcholine palmitoyl (LPC, C16:0) was from Cayman Chemical Co. (Ann Arbor, MI, USA); fatty acid-free bovine serum albumin (BSA) was from Calbiochem-Novabiochem Co. (San Diego, CA, USA); PTX was from List Biological Laboratories, Inc. (Campbell, CA, USA); and myo-[2$\left.{ }^{3} \mathrm{H}\right]$ inositol $(23.0 \mathrm{Ci} / \mathrm{mmol})$ was from American Radiolabeled Chemicals, Inc. (St. Louis, MO, USA). The D-erythro-form and L-threo-form of SPC were prepared by acid methanolysis of bovine brain sphingomyelin (Sigma-Aldrich) and following chromatographical separation as described previously (10).

\section{Preparation of receptor $c D N A$ plasmid and transfection}

The entire coding region of OGR1 (1098 bp, Genbank accession number: U48405) was amplified from the human cDNA library by RT-PCR. The respective amplified fragment was subcloned into the EcoRI site of the pEFneo expression vector for OGR1 (7). The DNA sequence was then confirmed. The 5 ' primers contained an EcoRI site, a Kozak sequence (CCACC), and the Nterminal region of the receptor. The 3 ' primers contained an EcoRI site and a stop codon in addition to the Cterminal region of the receptor. Chinese hamster ovary (CHO) cells were transfected with the OGR1 plasmid by electroporation, and the neomycin-resistant cells were selected as described previously (7). CHO cells resistant to G418 were used in bulk. OGR1 plasmid was also transfected into COS7 cells by electroporation to let them transiently express the receptor protein (7).

\section{Cell cultures}

Permanent cell line of $\mathrm{CHO}$ cells, which were transfected with empty plasmid (pEFneo) or OGR1 plasmid (pEFneoOGR1), was cultured in Dulbecco's modified Eagle's medium (DMEM) containing 10\% $(\mathrm{v} / \mathrm{v})$ fetal bovine serum (FBS) (Life Technologies) in a humidified air $/ \mathrm{CO}_{2}(19: 1)$ atmosphere. Unless otherwise stated, for the cAMP assay and inositol phosphate assay, the cells were plated on 12-multiplates. Twenty- four hours before the experiments, the medium was changed to TCM199 containing $2 \mu \mathrm{Ci}\left[{ }^{3} \mathrm{H}\right]$ inositol (in $1 \mathrm{ml}$ ) and $0.1 \%$ BSA. The $\left[{ }^{3} \mathrm{H}\right]$ inositol-labeled cells were used for both cAMP and inositol phosphate responses. PTX treatment of the cells was performed by adding the toxin $(100 \mathrm{ng} / \mathrm{ml})$ to the medium $18 \mathrm{~h}$ before the experiments. In some experiments (Fig. 3), cells were harvested from the dishes and used in suspension to measure the $\mathrm{Ca}^{2+}$ and cAMP responses. COS7 cells were transiently transfected with pEFneoOGR1 or pEFneo vector and cultured for 1 day in DMEM containing 10\% FBS and for another 1 day in TCM199 medium with $\left[{ }^{3} \mathrm{H}\right]$ inositol as described above for $\mathrm{CHO}$ cells in 12multiplates.

\section{cAMP accumulation and inositol phosphate production}

The cells in 12-multiplates were washed once and preincubated for $10 \mathrm{~min}$ at $37^{\circ} \mathrm{C}$ in the HEPES-buffered medium ( $\mathrm{pH}$ 7.6). The HEPES-buffered medium consisted of $20 \mathrm{mM}$ 4-(2-hydroxyethyl)-1-piperazineethanesulfonic acid (HEPES) ( $\mathrm{pH} 7.6), 134 \mathrm{mM} \mathrm{NaCl}$, $4.7 \mathrm{mM} \mathrm{KCl}, 1.2 \mathrm{mM} \mathrm{KH} \mathrm{PO}_{4}, 1.2 \mathrm{mM} \mathrm{MgSO}$, $2 \mathrm{mM}$ $\mathrm{CaCl}_{2}, 2.5 \mathrm{mM} \mathrm{NaHCO}$, $5 \mathrm{mM}$ glucose, and $0.1 \%$ $(\mathrm{w} / \mathrm{v})$ BSA (fraction $\mathrm{V})$. The cells were then incubated for $30 \mathrm{~min}$ under the indicated $\mathrm{pH}$ in the presence of $0.5 \mathrm{mM}$ 3-isobutyl-1-methylxanthine (IBMX) and $10 \mathrm{mM} \mathrm{LiCl}$ in a final volume of $0.7 \mathrm{ml}$. In order to cover a wider $\mathrm{pH}$ range, the incubation medium was buffered with the mixture of HEPES/N'-(2-hydroxyethyl)piperazine- $N^{\prime}$-3-propanesulphonic acid (EPPS)/2( $N$-morpholino)ethanesulphonic acid (MES) (8 mM each). Where indicated, appropriate test agents were supplemented with the incubation medium. All data in this report are referenced to $\mathrm{pH}$ at room temperature. The reaction was terminated by adding $100 \mu \mathrm{l}$ of $1 \mathrm{~N}$ $\mathrm{HCl}$. Cyclic AMP in the acid extract was measured by radioimmunoassay and total inositol phosphates including inositol mono-, di-, and tri-phosphate were measured as described previously (11).

In Fig. 3, the cells were cultured in 10-cm dishes and then the cells were harvested with trypsin (11). The cells were washed once with the HEPES-buffered medium $(\mathrm{pH} 7.6)$ and suspended with the same medium $\left(1 \times 10^{6}\right.$ cells $/ \mathrm{ml})$. The cell suspensions $(100 \mu \mathrm{l})$ were incubated with U72122, U73343, or vehicle (1\% DMSO in $100 \mu \mathrm{l})$ in the presence of $0.5 \mathrm{mM}$ IBMX for $1 \mathrm{~min}$ at $\mathrm{pH} 7.6$, and then $5 \mu \mathrm{l}$ of appropriate concentration of $\mathrm{HCl}$ was added to obtain the intended $\mathrm{pH}$; then the cells were further incubated for $2 \mathrm{~min}$. Reaction was terminated by adding $30 \mu \mathrm{l}$ of $1 \mathrm{~N} \mathrm{HCl}$. Cyclic AMP in the acid extract was measured by radioimmunoassay (11). 


\section{Measurement of $\left[\mathrm{Ca}^{2+}\right]_{i}$}

In Fig. 3, CHO cells were harvested from the dishes with trypsin as described above, and then $\left[\mathrm{Ca}^{2+}\right]_{\mathrm{i}}$ was measured based on the fluorescence change of Fura-2labeled cells as previously described (11).

\section{Data presentation}

All experiments were performed in duplicate or triplicate. The results of multiple observations are presented as the mean \pm S.E.M. from more than three different batches of cells unless otherwise stated. Statistical significance was assessed by Student's $t$-test; values were considered significant at $P<0.05$.

\section{Results}

OGR1 stimulation by extracellular acidification leads to adenylyl cyclase activation as well as phospholipase $C$ activation

Consistently with previous studies $(2,7)$, CHO cells transfected with OGR1 showed a very high inositol phosphate response to neutral-to-acidic $\mathrm{pH}$ with a halfmaximal effective $\mathrm{pH}$ of 7.1, whereas vector-transfected cells hardly affected the cellular activity under the same conditions (Fig. 1A). The increase in the inositol phosphate response was accompanied by an increase in $\left[\mathrm{Ca}^{2+}\right]_{\mathrm{i}}$ (Fig. 1: B and C). In this case, however, acidic $\mathrm{pH}$ significantly increased $\left[\mathrm{Ca}^{2+}\right]_{i}$ in vector-transfected cells as well, although there was no significant inositol phosphate response (Fig. 1A) and no detectable mRNA expression of OGR1 and other proton-sensing receptors including TDAG8, G2A, and GPR4, by Northern blotting in the cells (data not shown). Uncharacterized proton-sensing receptors other than the OGR1 family of receptors or receptor-independent mechanisms may mediate the $\mathrm{Ca}^{2+}$ response that might be independent of phospholipase $\mathrm{C}$. In any event, OGR1-transfected cells exhibited a higher $\mathrm{Ca}^{2+}$ response to acidic $\mathrm{pH}$ than the vector-transfected cells. The half-maximal effective $\mathrm{pH}$ of the OGR1-dependent $\mathrm{Ca}^{2+}$ response was estimated to be around $\mathrm{pH} 7.3$ to 7.2 (Fig. 1C), which is comparable to that of the inositol phosphate response (Fig. 1A). The higher responses in OGR1-transfected cells compared with vector-transfected cells were specific to protons. Thus, there was no significant difference in the P2-purinergic agonist ATP-induced inositol phosphate response (Fig. 1A, inset) and $\mathrm{Ca}^{2+}$ response (Fig. 1C, inset) at $\mathrm{pH} 7.6$ between the OGR1-transfected cells and the vector cells.

The change in extracellular $\mathrm{pH}$ also induced a remarkable cAMP accumulation in the presence of phosphodiesterase inhibitor IBMX in a time (Fig. 1D) and proton concentration (Fig. 1E)-dependent manner in
OGR1-transfected cells, whereas no significant cAMP response to $\mathrm{pH}$ was detected in vector-transfected cells (Fig. 1: D and E). $\mathrm{PGE}_{2}$ induced cAMP accumulation in OGR1-transfected cells to a similar extent to that in vector-transfected cells at $\mathrm{pH} 7.6$ (Fig. 1E, inset). Thus, the stimulation of OGR1 by lowering the extracellular $\mathrm{pH}$ resulted in the stimulation of not only inositol phosphate production but also cAMP accumulation, probably reflecting the activation of phospholipase $\mathrm{C}$ and adenylyl cyclase, respectively. The proton-dependent response curve, however, showed that phospholipase $\mathrm{C}$ activation (Fig. 1A) and $\mathrm{Ca}^{2+}$ response (Fig. 1C) are more sensitive to acidification than adenylyl cyclase activation (Fig. 1E).

Since no previous study had reported that OGR1 stimulation leads to cAMP accumulation, we further characterized the mechanism underlying the cAMP response. In wild-type COS7 cells, no detectable activity of inositol phosphate production and cAMP accumulation was observed in response to acidic $\mathrm{pH}$ (data not shown). In Fig. 2, we transiently transfected OGR1 cDNA into COS7 cells. Consistently with the result obtained with OGR1-expressing CHO cells, lowering the extracellular $\mathrm{pH}$ induced both inositol phosphate production and cAMP accumulation in OGR1-transfected COS7 cells. In this case again, inositol phosphate production was more sensitive to extracellular $\mathrm{pH}$ than cAMP accumulation; the half-maximal effective $\mathrm{pH}$ was roughly 7.0 for the inositol phosphate response and 6.7 for the cAMP response (Fig. 2). We also observed the cAMP response to acidic $\mathrm{pH}$ in OGR1-transfected RH7777 cells (data not shown).

Stimulation of $\mathrm{Ca}^{2+}$ signaling sometimes leads to the activation of adenylyl cyclase through $\mathrm{Ca}^{2+} /$ calmodulin (12) and prostaglandin production (13). In Fig. 3, OGR1-transfected CHO cells were treated with U73122, a phospholipase $\mathrm{C}$ inhibitor, which caused a remarkable inhibition of the proton-induced $\left[\mathrm{Ca}^{2+}\right]_{\mathrm{i}}$ increase (Fig. 3A). U73343, an inactive analogue of U73122, was ineffective in inhibiting the $\mathrm{Ca}^{2+}$ response, suggesting a specific action of U73122. Under the conditions of the present study, proton-induced cAMP accumulation was not appreciably affected by either U73122 or U73343 (Fig. 3B). Moreover, potent cyclooxygenase inhibitors, indomethacin and NS398, were ineffective to inhibit proton-induced cAMP accumulation (data not shown). Although acidification appreciably induced an increase in $\left[\mathrm{Ca}^{2+}\right]_{\mathrm{i}}$ in the vector-transfected cells (Fig. 1C), no significant cAMP accumulation was observed under these conditions (data not shown). These results suggest that a $\mathrm{pH}$-dependent increase in cAMP accumulation is not a secondary response to the stimulation of the $\mathrm{Ca}^{2+}$ and cyclooxygenase signaling pathways. 
A

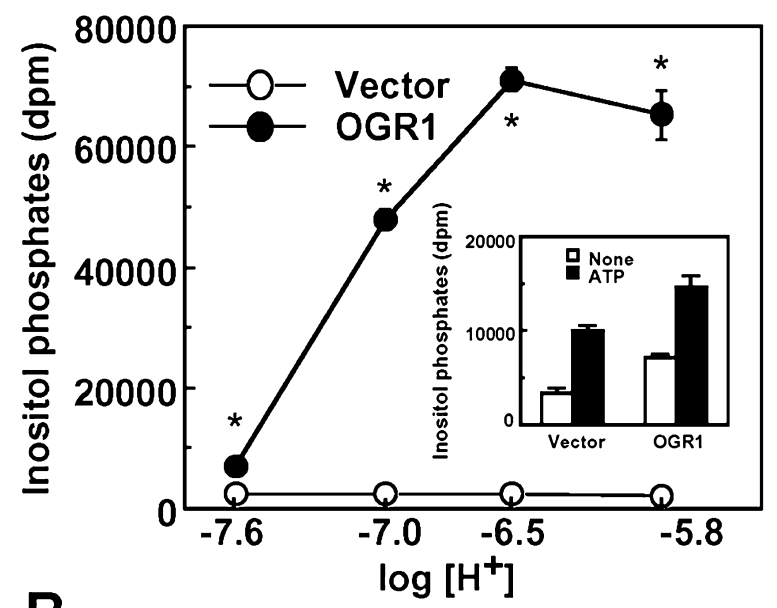

B
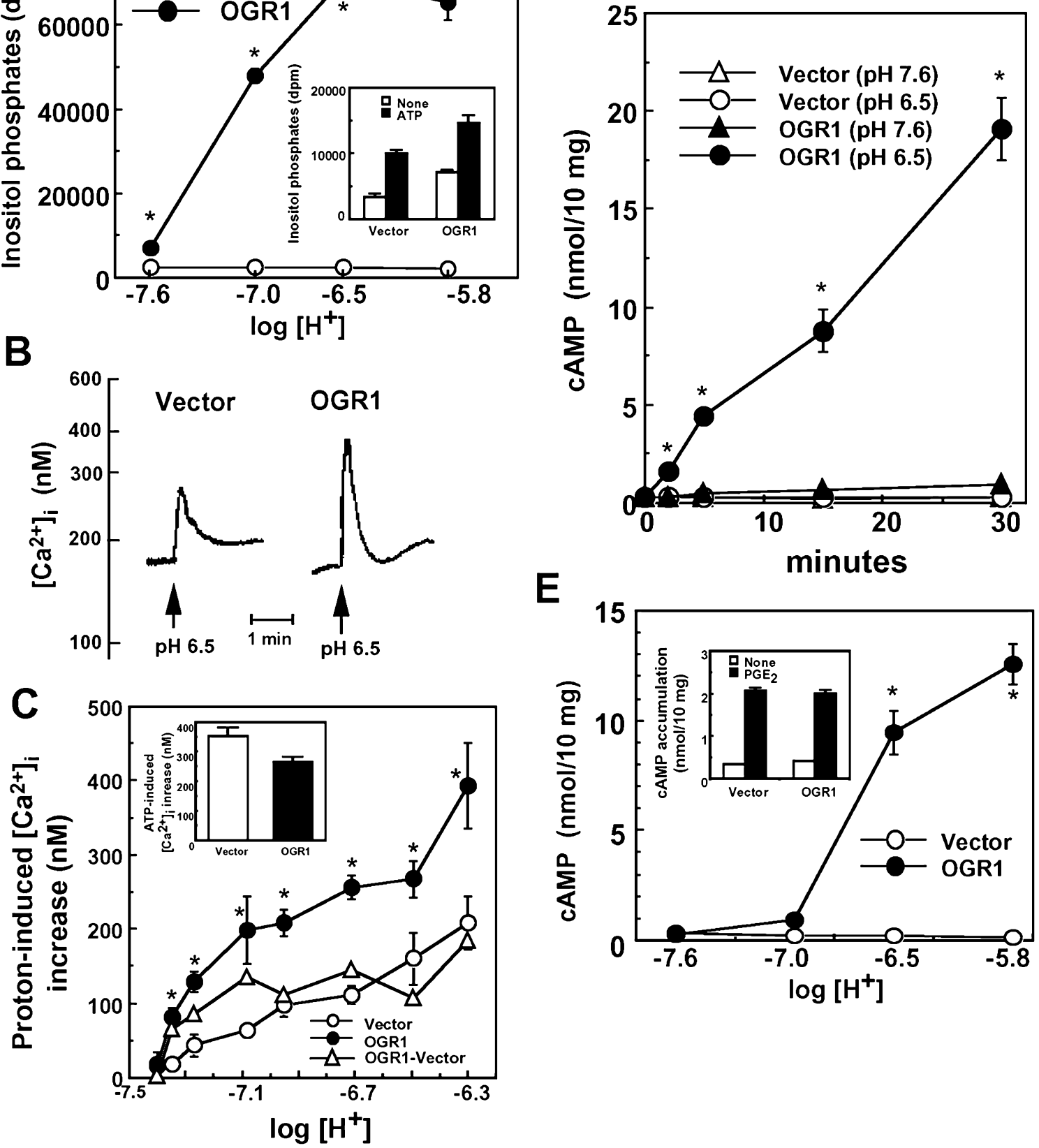

E

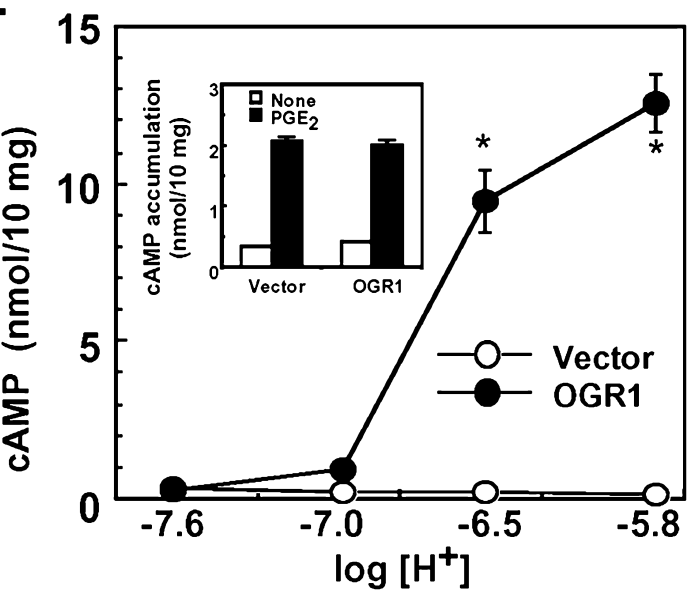

Fig. 1. Acidification induced inositol phosphate production (A), $\left[\mathrm{Ca}^{2+}\right]_{i}$ increase (B and C), and cAMP accumulation (D and E) in OGR1-transfected CHO cells. In A, vector-transfected cells (open circle) and OGR1-transfected cells (closed circle), which had been labeled with $\left[{ }^{3} \mathrm{H}\right]$ inositol, were incubated for $30 \mathrm{~min}$ to measure inositol phosphate production under the indicated $\mathrm{pH}$. In the inset, the cells were similarly incubated with or without $100 \mu \mathrm{M}$ ATP. In B and C, the cells were harvested from the dishes and $\left[\mathrm{Ca}^{2+}\right]_{i}$ was measured. The typical trace of $\left[\mathrm{Ca}^{2+}\right]_{i}$ change by acidification ( $\left.\mathrm{pH} 6.5\right)$ was shown in vector- and OGR1transfected cells (B). $\left[\mathrm{Ca}^{2+}\right]_{\mathrm{i}}$ increase by the indicated $\mathrm{pH}$ (increment from the basal value at $\mathrm{pH}$ 7.6) at around $15 \mathrm{~s}$ (the maximal value) was measured (C). The difference in $\left[\mathrm{Ca}^{2+}\right]_{\mathrm{i}}$ levels between vector- and OGR1-transfected cells at the indicated $\mathrm{pH}$ was plotted as an OGR1-dependent $\mathrm{Ca}^{2+}$ response (triangle). In the inset, $\left[\mathrm{Ca}^{2+}\right]_{\mathrm{i}}$ increase by ATP $(1 \mu \mathrm{M})$ at $\mathrm{pH} 7.6$ was measured. In D, cAMP accumulation under $\mathrm{pH} 7.6$ and 6.5 in vector- and OGR1-transfected cells is shown. In E, cAMP accumulation was measured in the same sample as those used for the inositol phosphate response in (A). In the inset, the cells were incubated for 30 min with or without $\mathrm{PGE}_{2}(1 \mu \mathrm{M})$ to measure cAMP accumulation. The results shown are the mean \pm S.E.M. of six values of three separate experiments except for panel $\mathrm{B}$. The asterisk $\left(^{*}\right)$ indicates that the effects of OGR1 transfection were significant under the indicated time and $\mathrm{pH}$. 


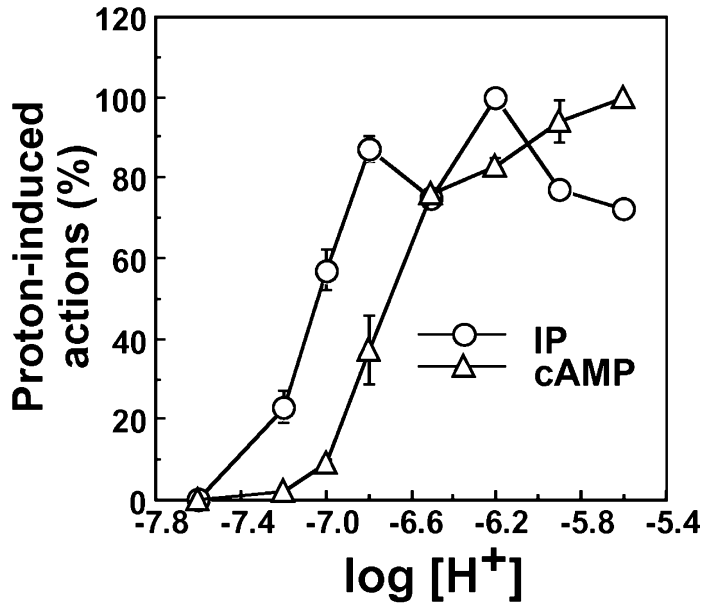

Fig. 2. Induction of both inositol phosphate production and cAMP accumulation in response to acidic $\mathrm{pH}$ in OGR1-transfected COS7 cells. COS7 cells were transiently transfected with $20 \mu \mathrm{g}$ of pEFneoOGR1 and labeled with $\left[{ }^{3} \mathrm{H}\right]$ inositol. Inositol phosphate response and cAMP response to the indicated $\mathrm{pH}$ for $30 \mathrm{~min}$ were assayed in the same sample as described in Materials and Methods. Results are expressed as percentages of the maximal response, $76307 \pm 12374$ $\mathrm{dpm}$ at $\mathrm{pH} 6.2$ for the inositol phosphate response and $5.27 \pm 0.41$ $\mathrm{nmol} / 10 \mathrm{mg}$ proteins at $\mathrm{pH} 5.6$ for the cAMP response. The results shown are the mean \pm S.E.M. of six values of three separate experiments.

SPC fails to stimulate but rather antagonizes OGR1mediated signaling pathways

OGR1 was initially identified as an SPC-specific receptor whose activation leads to the activation of phospholipase $\mathrm{C}$ and ERK (1). We tried to observe the OGR1-dependent agonistic SPC actions. However, neither D-SPC nor L-SPC appreciably affected the basal activity of inositol phosphate production and cAMP accumulation at $\mathrm{pH} 7.6$ in OGR1-transfected $\mathrm{CHO}$ cells (Fig. 4). On the other hand, acidification-induced inositol phosphate production (Fig. 4A) and cAMP accumulation (Fig. 4B) were inhibited by SPC in a manner dependent on extracellular $\mathrm{pH}$. Thus, the protondependent response curves were shifted to the right in the presence of either D-SPC or L-SPC. In addition, psychosine and glucosylsphingosine (glucopsychosine), but not LPC and sphingosine, were effective to inhibit acidification-induced actions; the rank order of the inhibition was psychosine $>\mathrm{D}-\mathrm{SPC}=\mathrm{L}-\mathrm{SPC}=$ glucopsychosine (Fig. 4: C and D). No inhibitory effects of the lysolipids were observed for the ATP-induced inositol phosphate response at $\mathrm{pH} 7.6$ (Fig. 4E).

\section{Discussion}

OGR1 was initially identified as a receptor for SPC coupling to the phospholipase $\mathrm{C}$ and ERK signaling
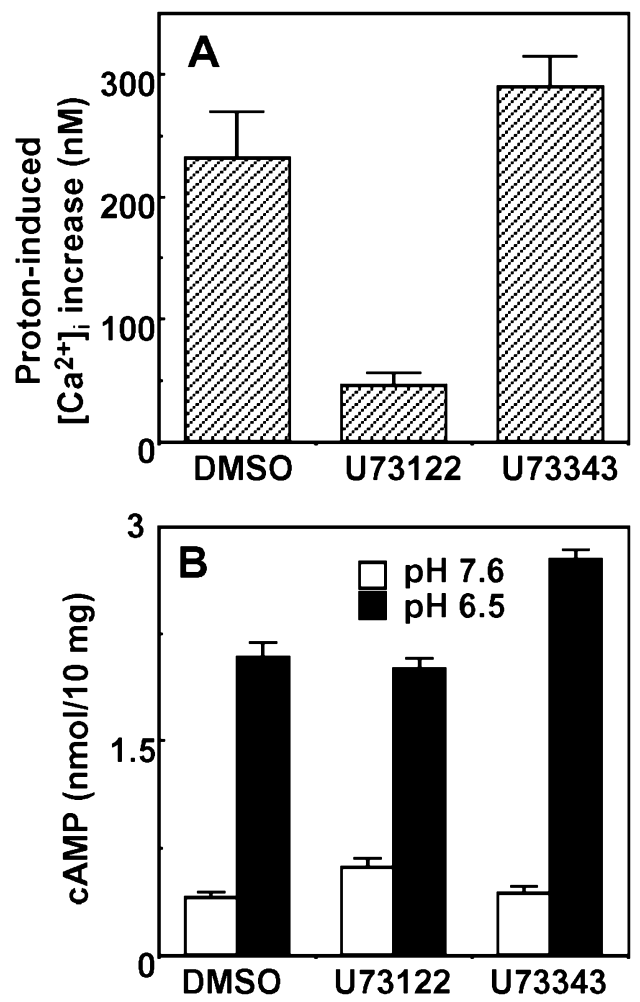

Fig. 3. Acidification-induced cAMP accumulation is independent of phospholipase C. OGR1-transfected $\mathrm{CHO}$ cells were harvested from the dish and used as a suspension. The cells were preincubated for 1 min with U73122 $(5 \mu \mathrm{M})$, U73343 $(5 \mu \mathrm{M})$, or DMSO and then incubated for $2 \mathrm{~min}$ at either $\mathrm{pH} 7.6$ or $\mathrm{pH}$ 6.5. The acidification-induced increase in $\left[\mathrm{Ca}^{2+}\right]_{\mathrm{i}}$ is shown in (A) and the cAMP level at the respective $\mathrm{pH}$ is shown in (B). Results are the mean \pm S.E.M. of 6 to 9 values of three separate experiments.

pathways (1) and has now been recognized to be a proton-sensing receptor that causes the production of inositol phosphate reflecting the activation of phospholipase $\mathrm{C}$ in response to extracellular acidification (2). In the present study, we showed that extracellular acidification induced cAMP accumulation, probably reflecting the activation of adenylyl cyclase, in addition to inositol phosphate production, in OGR1expressing cells, although a more acidic condition was required for the maximal response in cAMP accumulation compared with inositol phosphate production. The cAMP response does not seem to depend on phospholipase $\mathrm{C}$ activity and $\left[\mathrm{Ca}^{2+}\right]_{\mathrm{i}}$. Thus, OGR1 may be coupled to an adenylyl cyclase system, similarly to other $\mathrm{G}_{\mathrm{s}}$-coupled receptors, although the possibility that cAMP accumulation is an indirect or secondary response cannot be completely excluded.

Ludwig et al. (2) showed that five extracellular histidine residues might be involved in the protonsensing mechanism. Thus, the substitution of histidine to phenylalanine in these positions on OGR1 receptor 

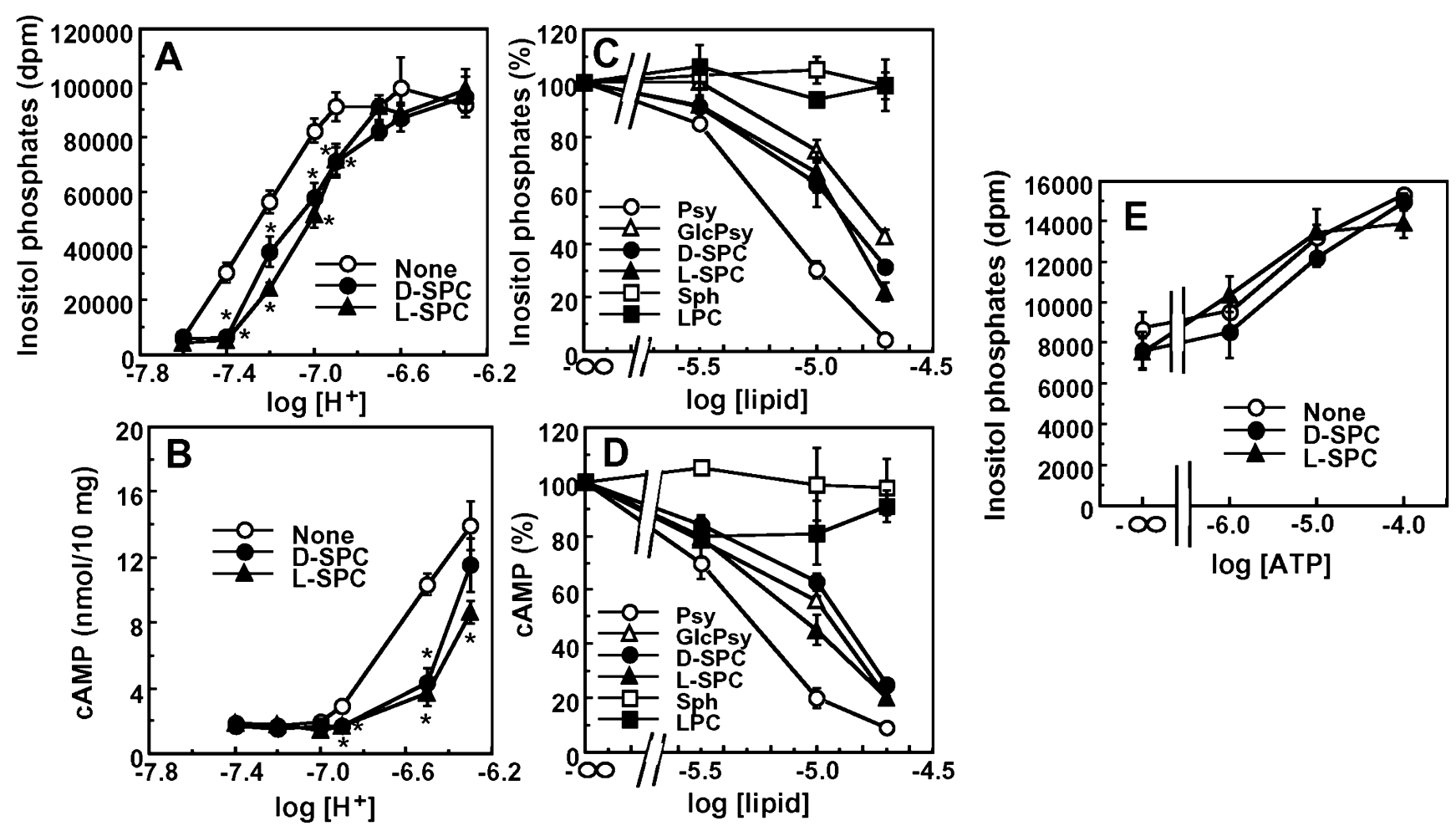

Fig. 4. SPC and its related lysolipids inhibited $\mathrm{pH}$-dependent responses in the OGR1-transfected $\mathrm{CHO}$ cells. In A and B, OGR1-transfected CHO cells were incubated for the inositol phosphate response (A) and cAMP response (B) to the indicated $\mathrm{pH}$ with or without $15 \mu \mathrm{M}$ D-erythro-SPC or L-threo-SPC. The basal values at $\mathrm{pH} 7.6$ were $6229 \pm 164 \mathrm{dpm}$ for "None", $5923 \pm 784 \mathrm{dpm}$ for D-SPC, and $4432 \pm 149 \mathrm{dpm}$ for L-SPC in (A) and $1.86 \pm 0.05 \mathrm{nmol} / 10 \mathrm{mg}$ for "None", $1.69 \pm 0.06 \mathrm{nmol} / 10 \mathrm{mg}$ for D-SPC, and $1.87 \pm 0.11 \mathrm{nmol} / 10 \mathrm{mg}$ for L-SPC in (B). Note that neither D-SPC nor L-SPC exerted stimulatory effects on these basal activities. In C and D, the OGR1 cells were incubated at pH 7.0 for the inositol phosphate response (C) and at $\mathrm{pH} 6.5$ for the cAMP response in the presence of the indicated concentrations of psychosine (Psy), glucosylsphingosine (GlcPsy), D-SPC, L-SPC, sphingosine (Sph), or lysophosphatidylcholine (LPC). Results are expressed as percentages of control values without test agents. These control values were $71166 \pm 2260 \mathrm{dpm}$ for inositol phosphate production (C) and $10.3 \pm 0.6 \mathrm{nmol} / 10 \mathrm{mg}$ proteins (D). In E, OGR1-transfected CHO cells were incubated for the inositol phosphate response to the indicated concentration of ATP in the presence or absence of $15 \mu \mathrm{M}$ each stereoisoform SPC. The results shown are the mean \pm S.E.M. of six values of three separate experiments $(A, B$, and $E)$ and the mean \pm S.E.M. of four values of two separate experiments $(\mathrm{C}$ and $\mathrm{D})$. The asterisk $(*)$ indicates that the effects of D-SPC and L-SPC were significant.

resulted in the attenuation of the inositol phosphate response at $\mathrm{pH} 6.8$; however, the activity was recovered at a more acidic $\mathrm{pH}$. Thus, the mutation of histidine residues shifted the dose-response curve of the extracellular protons to the right. Based on these studies, they proposed that hydrogen bonding between histidine residues stabilizes the inactive state of the receptors at a slightly alkaline $\mathrm{pH}$ and that the destruction of their bonding by protonation induces the active conformational change in the molecular structure of receptor that is favorable for coupling to G-proteins (2). The discrepancy in the proton requirement between the inositol phosphate $/ \mathrm{Ca}^{2+}$ response and the cAMP response might reflect the participation of different histidine residue(s) that are critical for the induction of a conformational change in the coupling to $\mathrm{G}_{\mathrm{q}}$ - and $\mathrm{G}_{\mathrm{s}}$-proteins. Alternatively, the difference in the degree of protonation of the histidine residues might determine the coupling to $\mathrm{G}_{\mathrm{q}^{-}}$or $\mathrm{G}_{\mathrm{s}}$-proteins. Further experiments are needed to understand the mechanism underlying acidificationinduced and OGR1-mediated adenylyl cyclase activation at the molecular level.

GPR4, TDAG8, and G2A, which form a subfamily of GPCRs with OGR1, have been previously described to be receptors for lysolipid mediators; GPR4 and G2A are the receptors for LPC and SPC $(3,4)$, and TDAG8 is the receptor for psychosine (5). These receptors are also known as proton-sensing GPCRs that sense an extracellular proton or $\mathrm{pH}$, resulting in the change in a variety of intracellular signaling pathways through Gproteins $(2,6-9)$. In the present study, we showed that SPC behaves as an antagonist against proton-induced actions in OGR1-expressing cells. Thus, we observed that the concentration-dependent curve of the extra- 
cellular proton on inositol phosphate production and cAMP accumulation shifted to the right by SPC (Fig. 4). We have previously reported that proton-induced cAMP accumulation through TDAG8 was antagonized by psychosine (7). Furthermore, the G2A-mediated inositol phosphate and Rho signaling pathways seem to be antagonized by LPC (6). Thus, previously proposed agonists for the subfamily of receptors seem to have the ability to antagonize the proton-induced actions, although their specificity as agonist and antagonist is not always the same. For example, psychosine, a proposed agonist for TDAG8, also behaves as an antagonist against the proton-sensing of OGR1 and GPR4, as does TDAG8, whereas the lipid has not been shown to exert an agonistic property for either OGR1 or GPR4 (7). Furthermore, D-erythro-SPC but not L-threo-SPC exhibited agonistic effects on OGR1 in a previous study (1), whereas the antagonistic action of SPC on proton-sensing appears to be streoisoform-independent; D-erythro-SPC and L-threo-SPC equally antagonized the proton-induced actions, as shown in the present study. Thus, the interaction of a lipid mediator with the receptor proteins as an agonist or an antagonist may be different at the molecular level. According to the histidine model proposed by Ludwig et al. (2), we assume that a lysolipid with an antagonist property interacts with histidine residues and thereby stabilizes the inactive unprotonated state or interferes with the protonation of histidine residues on receptor molecules critical for the conformational change to the active state. On the other hand, a lipid molecule with an agonistic property might interact with the receptor protein in a proton-independent manner to change the receptor conformation to the active state.

It should be noted, however, that the agonist actions of a certain group of lipids were not always confirmed, except for G2A. For example, we failed to observe the agonist activities of psychosine for TDAG8 (7) and of SPC for OGR1 (the present study) under the conditions in which $\mathrm{pH}$-dependent actions were observed. Other groups have also failed to detect agonist actions by SPC or LPC in OGR1- and GPR4-expressing cells $(2,14)$. In the case of G2A, however, exogenous LPC has been shown to induce the migration of $\mathrm{T}$ cells and macrophages in a G2A-dependent manner $(15,16)$, although the results of LPC binding experiments to G2A were withdrawn by the authors (17), who had initially proposed LPC as an agonist for G2A (4). Thus, the expression of the agonist action by lysolipids might require unidentified additional signals. Although further careful experiments are required for the characterization of lipid actions, the antagonistic property of lysolipids may be useful for the characterization of proton-sensing receptors in biological systems. In fact, we have successfully employed psychosine to determine the involvement of proton-sensing receptors in the extracellular protoninduced cAMP accumulation in thymocytes (7). Our present results showed that D-SPC and L-SPC were equally potent to inhibit proton-induced actions through OGR1. However, SPC is less effective than psychosine, and D-SPC is also an agonist for S1P receptors (18) and GPR12 (19). Psychosine, rather than SPC, is therefore recommended for such a purpose. Thus, psychosine may be a leading compound for the future development of more sensitive and specific antagonists for proton-sensing GPCRs, which may be involved in several circumstances including inflammation, cancer, and ischemia.

In conclusion, the acidification of extracellular $\mathrm{pH}$ induces OGR1 stimulation, leading to the activation of adenylyl cyclase and phospholipase C. The protoninduced activation of the OGR1-mediated signaling pathways was antagonized by SPC and related lysolipids, which may be useful tools for the characterization of proton-sensing GPCRs, including OGR1.

\section{Acknowledgments}

We are grateful to Ms. Chisuko Uchiyama for her technical assistance. This work was supported by a Grants-in-Aid for scientific research from the Japan Society for the Promotion of Science; a grant of the 21st Century COE Program from the Ministry of Education, Culture, Sports, Science, and Technology of Japan; and grants from The Nakatomi Foundation and Uehara Memorial Foundation.

\section{References}

1 Xu Y, Zhu K, Hong G, Wu W, Baudhuin LM, Xiao Y, et al. Sphingosylphosphorylcholine is a ligand for ovarian cancer G-protein-coupled receptor 1. Nat Cell Biol. 2000;2:261-267.

2 Ludwig MG, Vanek M, Guerini D, Gasser JA, Jones CE, Junker $\mathrm{U}$, et al. Proton-sensing G-protein-coupled receptors. Nature. 2003;425:93-98.

3 Zhu K, Baudhuin LM, Hong G, Williams FS, Cristina KL, Kabarowski JH, et al. Sphingosylphosphorylcholine and lysophosphatidylcholine are ligands for the $G$ protein-coupled receptor GPR4. J Biol Chem. 2001;276:41325-41335.

4 Kabarowski JH, Zhu K, Le LQ, Witte ON, Xu Y. Lysophosphatidylcholine as a ligand for the immunoregulatory receptor G2A. Science. 2001;293:702-705.

5 Im DS, Heise CE, Nguyen T, O’Dowd BF, Lynch KR. Identification of a molecular target of psychosine and its role in globoid cell formation. J Cell Biol. 2001;153:429-434.

6 Murakami N, Yokomizo T, Okuno T, Shimizu T. G2A is a proton-sensing G-protein-coupled receptor antagonized by lysophosphatidylcholine. J Biol Chem. 2004;279:42484-42491. 
7 Wang JQ, Kon J, Mogi C, Tobo M, Damirin A, Sato K, et al. TDAG8 is a proton-sensing and psychosine-sensitive G-proteincoupled receptor. J Biol Chem. 2004;279:45626-45633.

8 Ishii S, Kihara Y, Shimizu T. Identification of T cell deathassociated gene 8 (TDAG8) as a novel acid sensing G-proteincoupled receptor. J Biol Chem. 2005;280:9083-9087.

9 Radu CG, Nijagal A, McLaughlin J, Wang L, Witte ON. Differential proton sensitivity of related $G$ protein-coupled receptors $\mathrm{T}$ cell death-associated gene 8 and G2A expressed in immune cells. Proc Natl Acad Sci USA. 2005;102:1632-1637.

10 Bunemann M, Liliom K, Brandts BK, Pott L, Tseng JL, Desiderio DM, et al. A novel membrane receptor with high affinity for lysosphingomyelin and sphingosine 1-phosphate in atrial myocytes. Embo J. 1996;15:5527-5534.

11 Kon J, Sato K, Watanabe T, Tomura H, Kuwabara A, Kimura T, et al. Comparison of intrinsic activities of the putative sphingosine 1-phosphate receptor subtypes to regulate several signaling pathways in their cDNA-transfected Chinese hamster ovary cells. J Biol Chem. 1999;274:23940-23947.

12 Defer N, Best-Belpomme M, Hanoune J. Tissue specificity and physiological relevance of various isoforms of adenylyl cyclase. Am J Physiol Renal Physiol. 2000;279:F400-F416.

13 Damirin A, Tomura H, Komachi M, Tobo M, Sato K, Mogi C, et al. Sphingosine 1-phosphate receptors mediate the lipid- induced cAMP accumulation through cyclooxygenase-2 /prostaglandin I2 pathway in human coronary artery smooth muscle cells. Mol Pharmacol. 2005;67:1177-1185.

14 Bektas M, Barak LS, Jolly PS, Liu H, Lynch KR, Lacana E, et al. The G protein-coupled receptor GPR4 suppresses ERK activation in a ligand-independent manner. Biochemistry. 2003;42:12181-12191.

15 Radu CG, Yang LV, Riedinger M, Au M, Witte ON. T cell chemotaxis to lysophosphatidylcholine through the G2A receptor. Proc Natl Acad Sci USA. 2004;101:245-250.

16 Yang LV, Radu CG, Wang L, Riedinger M, Witte ON. Giindependent macrophage chemotaxis to lysophosphatidylcholine via the immunoregulatory GPCR G2A. Blood. 2005;105:11271134.

17 Witte ON, Kabarowski JH, Xu Y, Le LQ, Zhu K. Retraction. Science. 2005;307:206.

18 Murata N, Sato K, Kon J, Tomura H, Okajima F. Quantitative measurement of sphingosine 1-phosphate by radioreceptorbinding assay. Anal Biochem. 2000;281:115-120.

19 Ignatov A, Lintzel J, Hermans-Borgmeyer I, Kreienkamp HJ, Joost P, Thomsen S, et al. Role of the G-protein-coupled receptor GPR12 as high-affinity receptor for sphingosylphosphorylcholine and its expression and function in brain development. J Neurosci. 2003;23:907-914. 